\title{
The Effect of Downsizing on Transformational Leadership, Organizational Climate, Organizational Commitment and Employee Performance
}

\author{
R. Djoko Andreas Navalino ${ }^{1}$, Umar Nimran ${ }^{2}$, Endang Siti Astuti ${ }^{3}$, \\ Djamhur Hamid ${ }^{4}$ \\ ${ }^{1}$ The Army College of Technology, Indonesia

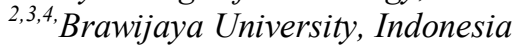

\begin{abstract}
The research was aimed to analize and explain the effect of downsizing on transformational leadership, organizational climate, organizational commitment and employee performance; transformational leadership on organizational climate, organizational commitment and employee performance; organizational climate on organizational commitment and employee performance; organizational commitment on employee performance of PT. Pindad (Persero). The research type is an explanatory research, which describes the influence among the research variables. The object of research units of PT. Pindad (Persero). The research population was the employees of PT. Pindad (Persero) who have experienced downsizing. The research sampling were 96 people. The research considers the Generalized Structured Component Analysis (GSCA) method to analize the data.

The result indicated that there were effects among variables in all hypotheses. Five of 10 hypotheses proposed were significant and 5 other hypotheses were unsignificant. Transformational leadership variable played an important role in effect of downsizing on other variables such as organizational climate, organizational commitment and employee performance. The result of research showed that downsizing through transformational leadership had positif and significant effect to organizational climate and organizational commitment. The other side the effect to employee performance was positif but unsignificant. The research then concluded that the optimization of downsizing must involve transformational leadership as a mediator.
\end{abstract}

Keywords: Downsizing, Transformational Leadership, Organizational Climate, Organizational Commitment, Employee Performance

\section{Introduction}

Downsizing is a systematic effort by the company to reduce the amount of labor in order to improve the efficiency and performance (Appelbaum, et al, 1987, 1999), but some researchers define it in a way that is slightly different (McKinley et al, 2000; Cascio \& Wynn, 2004). It is defined by Tsai \& Yen (2008) by using the term downsizing, organization downsizing, business downsizing; reorganization, right-sizing, de-layering, restructuring, redundancy, rationalization, redesigning, revitalization etc. Which is essentially a series of managerial actions taken by the company that aims to adjust to changes in the environment, overcoming the difficulties of management, increase efficiency, improve productivity and competitiveness (Tsai \& Yen, 2008). In streamlining the way used include cost reduction, restructuring and workforce reduction (employees). Of the three ways, the most important way, and as a last resort is a reduction in workforce. Robbins (1994) stated that downsizing is an organizational downsizing efforts or reduce the size of the organization by reducing the number of vertical levels. While Cascio (1993) states that the downsizing as a step to reduce the number of middle managers, expanding the range of organization control and encourage the delegation of authority. Thus downsizing refers to the planned elimination of positions or jobs.

Downsizing is a common euphemism referring to the purpose of reducing the size and cost of operating companies as well as by way of reducing the number of employees. For employees, downsizing can be very frightening and upsetting. This means that downsizing is necessary for management on the one side in a particular state, but so downsizing can also be a negative impact on organizational commitment (Theissen, 2004; Lee \& Corbett, 2006; Ericson \& Roloff, 2007) which is manifested in the form of underperformance (Lee \& Corbett, 2006). Decreasing organizational commitment can also have an impact on the rising levels of absenteeism and decreased productivity (Meyer et al, 1997; Lamsa \& Savolainen, 2000). In addition to giving effect to the commitment, downsizing can also impact the performance of the organization or company (eg Stassen et al., 2005; Tzafrir et al., 2006; Guthrie \& Datta, 2007; Sheaffer et al., 2009; Sitlington \& Marshall 2011 ). The negative impact of downsizing must be minimized to achieve the goal of implementation of downsizing itself. One of the method is through the role of transformational leadership. Because 
transformational leadership is one kind of leadership that tends to increase with the subordinate role with active communication.

Turknett (2009) in an article titled Revitalization after downsizing: A Briefing for Leaders, stated that the leaders of the post-downsizing should be able to provide an assessment of the remaining employees, have a clear knowledge on every mood, giving the commitment, energy, morale, etc. Such knowledge is essential for planning interventions that will produce the desired culture. Work to improve security, not by promising a job, but by providing information, increasing engagement, helping people be responsible for themselves including responsible for their own careers.

Transformational leadership is a leadership approach that builds awareness about the importance of the value of their subordinates and the work of their task (Bass, 1985). Furthermore, transformational leaders are also making efforts to change awareness increase, excite and inspire subordinates or members of the organization to spend extra effort in achieving organizational goals, without feeling pressured or stressed. That leadership is needed to bridge the interests of the organization to the employees, so that downsizing is expected to be implemented as planned. Based on these descriptions can be said that transformational leadership will have a positive influence on organizational climate (McMurray, et al, 2010) as well as on employee performance (Sandbakken, 2006). In addition, organizational climate can be a positive influence on organizational commitment (De Clercq \& Rius, 2007) as well as on organizational performance (Kangis \& Williams, 2000).

\section{Theory Frame Work}

\section{Downsizing, Organizational Climate, Organizational Commitment and Employee Performance}

The existence of downsizing will occur less conducive working atmosphere, because the employee was filled with anxiety due to the lack of certainty about the continuity of work in the future. This happens to employees who survived downsizing (survivors) that may affect their performance. Thus the first hypothesis can be formulated as follows

H1: Downsizing has a significant negative effect on organizational climate.

The existence of downsizing will bring apathy as a result of changes in psychological contracts, and can lead to decrease in organizational commitment (Theissen, 2004; Lee \& Corbett, 2006; Ericson \& Roloff, 2007). Downsizing also results in delays long-term commitment (Hitt et al., 1994). The decline in organizational commitment can have an impact on the rising levels of absenteeism and decreased productivity (Meyer et al, 1997; Lamsa \& Savolainen, 2000). Thus the second hypothesis can be formulated as follows.

H2: Downsizing has a significant negative effect on organizational commitment

Downsizing estimated to be the major cause of declining employee performance (Cameron et al., 1991). With the downsizing, the work that should be done by some people after any downsizing it must be done alone.

H3: Downsizing has a significant negative effect on the performance of employees

\section{Transformational Leadership, Organizational Climate, Organizational Commitment and Employee Performance}

From all sort of literatures, transformational leadership expressed a positive impact on organizational climate. As research conducted McMurray et al (2010) which uses a scale of transformational leadership states that the combination of transformational and transactional leadership had a positive influence on organizational climate.

H4: Transformational leadership has a significant positive effect on organizational climate.

Transformational leadership can have a positive impact on organizational climate (McMurray, et al., 2009). The combination of transformational and transactional leadership positively influence to organizational climate. Transformational leadership is able to provide peace, certainty and motivation to the follower which in this case is the employee. Thus providing a positive impact on organizational climate.

H5: Transformational leadership has a significant positive effect on organizational commitment

Transformational leadership can influence on organizational commitment (Ramachandran \& Krishnan, 2009). Due to the transformational leadership, leaders will develop/empower people by creating an enabling environment, then also stimulate people to be creative and innovative to search through the assumptions, the formulation of the problem, and the adjustment of the old situation in a new way, in addition to the leader behaves in a way to motivate parties- those around them by providing meaning and challenge to subordinate then act as a role model

H6: Transformational leadership has a significant positive effect on employee performance

Downsizing and Transformational Leadership

Downsizing is done mainly in order to efficiency but in practice it often doesn't get the expected results (Cascio et. al., 1997). Therefore, if needs of a form of leadership that will support the implementation of downsizing (Turknett, 2009). The right leadership to support the implementation of the downsizing is transformational leadership. Transformational leadership is visionary leadership that invites followers to look 
away. Both the future of the organization/company and the employees themselves. Thus the existence of downsizing will lead to transformational leadership or in other words, downsizing will affect positively to transformational leadership.

H7: Downsizing has a positive significant effect on transformational leadership

\section{Methods}

The research was conducted in PT. Pindad Indonesia. Number of quetionnaires that were colleted were 96 respondents from 2.014 employee who have experienced downsizing. The research was using Generalized Structured Component Analysis (GSCA) using GeSCA software online.

Measurement of research constructs (unobserved variables) performed through reflective indicator measurement scale using a Likert Scale technique. Downsizing construct adopt Robbins (1994), Cascio (1993) and Tsai Yen (2008) with 3 indicators. Measurement of transformational leadership adopt Bass (1985) with 4 indicators. Measurement of organizational climate using Organizational Climate Measure (OCM) based upon Quinn and Rohrbaugh's Competing Values model that developed by Patterson, et al. (2005) with 4 indicators. Organizational commitment measured using indicators adapted from Allen \& Meyer (1991; 1997) with 3 indicators. Indicators used to measure employee performance adapted from Gomes (2002) with 4 indicators. All indicator will be shown in appendix 1 .

\section{Model Measurement (Outer Model)}

\section{Analysis and Result}

This model specifies the relationship between the latent variable indicators or it can be said that the outer model defines how each indicator relates to the latent variables. Test conducted on the outer models include.

\section{Convergent Validity}

Convergent validity value is the value of loading factor on the latent variable indicators. The expected value of $>0.7$ and significant. In table 1 shows that value convergent validity on each indicator.

Table 1. Convergent Validity

\begin{tabular}{|c|c|c|c|c|c|c|c|c|}
\hline \multirow[t]{2}{*}{ Indicator } & \multicolumn{2}{|c|}{ Loading } & \multirow[t]{2}{*}{ Indicator } & \multicolumn{2}{|c|}{ Loading } & \multirow[t]{2}{*}{ Indicator } & \multicolumn{2}{|c|}{ Loading } \\
\hline & Estimate & CR & & Estimate & $\mathbf{C R}$ & & Estimate & $\mathbf{C R}$ \\
\hline DS.1 & 0.789 & $22.04^{*}$ & OCL.1 & 0.726 & $15.48^{*}$ & OCM.1 & 0.799 & $27.33^{*}$ \\
\hline DS.2 & 0.797 & $18.08^{*}$ & OCL.2 & 0.737 & $15.71^{*}$ & ОСМ.2 & 0.784 & $22.03^{*}$ \\
\hline DS.3 & 0.843 & $26.92^{*}$ & OCL.3 & 0.715 & $12.89^{*}$ & ОСМ.3 & 0.655 & $11.28^{*}$ \\
\hline DS.4 & 0.827 & $19.61^{*}$ & OCL.4 & 0.736 & $15.52^{*}$ & ОСМ.4 & 0.633 & $9.46^{*}$ \\
\hline DS.5 & 0.819 & $22.57^{*}$ & OCL.5 & 0.835 & $30.16^{*}$ & ОСМ.5 & 0.762 & $17.95^{*}$ \\
\hline DS.6 & 0.655 & $8.8^{*}$ & OCL.6 & 0.761 & $14.03^{*}$ & ОСМ.6 & 0.631 & $9.23^{*}$ \\
\hline DS.7 & 0.768 & $18.92^{*}$ & OCL.7 & 0.795 & $18.95^{*}$ & ОСМ.7 & 0.742 & $19.15^{*}$ \\
\hline DS.8 & 0.682 & $10.47^{*}$ & OCL.8 & 0.705 & $13.08^{*}$ & ОСМ.8 & 0.718 & $14.16^{*}$ \\
\hline DS.9 & 0.716 & $13.38^{*}$ & OCL.9 & 0.662 & $11.1^{*}$ & ОСМ.9 & 0.693 & $11.54^{*}$ \\
\hline DS.10 & 0.666 & $11.66^{*}$ & OCL.10 & 0.773 & $22.38^{*}$ & OCM.10 & 0.739 & $17.59^{*}$ \\
\hline DS.11 & 0.768 & $21.37^{*}$ & OCL.11 & 0.778 & $23.36^{*}$ & OCM.11 & 0.668 & $10.59^{*}$ \\
\hline DS.12 & 0.630 & $7.43^{*}$ & OCL.12 & 0.674 & $9.59^{*}$ & OCM.12 & 0.782 & $17.26^{*}$ \\
\hline DS.13 & 0.701 & \begin{tabular}{|l|}
$12.31^{*}$ \\
\end{tabular} & OCL.13 & 0.717 & $14.99^{*}$ & & & \\
\hline & & & & & & EP.1 & 0.770 & $20.57^{*}$ \\
\hline TL.1 & 0.760 & \begin{tabular}{|l|}
$25.72^{*}$ \\
\end{tabular} & TL.14 & 0.623 & $8.7^{*}$ & EP.2 & 0.809 & $25.56^{*}$ \\
\hline TL.2 & 0.691 & $14.71^{*}$ & TL.15 & 0.649 & $12.84^{*}$ & EP.3 & 0.730 & $15.48^{*}$ \\
\hline TL.3 & 0.755 & $19.51^{*}$ & TL.16 & 0.698 & $16.13^{*}$ & EP.4 & 0.752 & $17.35^{*}$ \\
\hline TL.4 & 0.686 & $11.35^{*}$ & TL.17 & 0.669 & $12.22^{*}$ & EP.5 & 0.759 & $19.37^{*}$ \\
\hline TL.5 & 0.800 & $21.45^{*}$ & & & & EP.6 & 0.807 & $25.47^{*}$ \\
\hline TL.6 & 0.628 & $9.29^{*}$ & & & & EP.7 & 0.734 & $16.42^{*}$ \\
\hline TL.7 & 0.784 & $19.86^{*}$ & & & & EP.8 & 0.686 & $13.3^{*}$ \\
\hline TL.8 & 0.739 & $16.68^{*}$ & & & & EP.9 & 0.776 & $18.47^{*}$ \\
\hline TL.9 & 0.748 & $16.48^{*}$ & & & & EP.10 & 0.815 & $27.14^{*}$ \\
\hline TL.10 & 0.726 & $13.84^{*}$ & & & & EP.11 & 0.694 & $13.75^{*}$ \\
\hline TL.11 & 0.682 & $12.02^{*}$ & & & & EP.12 & 0.659 & $14.38^{*}$ \\
\hline TL.12 & 0.679 & $11.91^{*}$ & & & & EP.13 & 0.646 & $10.62^{*}$ \\
\hline TL.13 & 0.746 & $17.48^{*}$ & & & & EP.14 & 0.716 & $15.51^{*}$ \\
\hline
\end{tabular}

$\mathrm{CR}^{*}=$ significant at .05 level 
All the indicators have outer loading (loading estimate) greater than 0.5 and significant. All indicators can be used in testing the research model because adequate convergent validity.

\section{Discriminant Validity}

Discriminant validity test is used to see whether a specific indicator of the latent variable is completely different from indicators of other latent variables, so that the indicator is really worthy to explain the latent variables. Discriminant validity test is done by looking at the root of the average variance extraced value (AVE) for each latent construct and compare it with the correlation between the constructs. If the root of the AVE value of each construct was greater than the value of the correlation between the construct with other constructs in the model, then it is said adequate discriminant validity. To determine the discriminant validity of the test results in this study, can be seen in the following table:

Table 2. Discriminant Validity

\begin{tabular}{|c|c|}
\hline Latent Variabel & Average Variance Extracted (AVE) \\
\hline DS & 0.557 \\
\hline TL & 0.506 \\
\hline OCL & 0.549 \\
\hline OCM & 0.517 \\
\hline EP & 0.550 \\
\hline
\end{tabular}

Table 2 shows that the value of the entire construct AVE greater than 0.5, so it can be concluded that the entire construct is a good model, so that all the constructs in the model has adequate discriminant validity.

\section{Composite Reliability}

The third part of the outer model is composite reliability. Composite reliability showed the reliability values between blocks of indicators that established the constructs. Constructs expressed either reliable or if the value of composite reliability and Cronbach alpha above 0.7 . Below is a table of the results of the reliability of the composite output GSCA:

Table 3. Composite Reliability

\begin{tabular}{|c|c|}
\hline Variabel & Cronbach Alpha \\
\hline DS & 0.930 \\
\hline TL & 0.938 \\
\hline OCL & 0.929 \\
\hline OCM & 0.915 \\
\hline EP & 0.936 \\
\hline
\end{tabular}

Based on the table above may be seen Composite reliability values for variables downsizing of 0.930 , 0.938 for transfomasional Leadership, Organizational Climate for 0.929 , amounting to 0.915 Organizational Commitment, and Employee Performance for 0.936, where the value of the fifth Composite reliability constructs in the model are all greater than 0.70 , so it can be said that the outer measurement model or outer model with reflexive indicator has good reliability. Thus it can be said that the indicators of downsizing, transfomasional Leadership, Organizational Climate, Organizational Commitment and Employee Performance, actually mutually reinforcing latent variables or actually being able to measure latent variables. 


\section{Structural Model (Inner Model)}

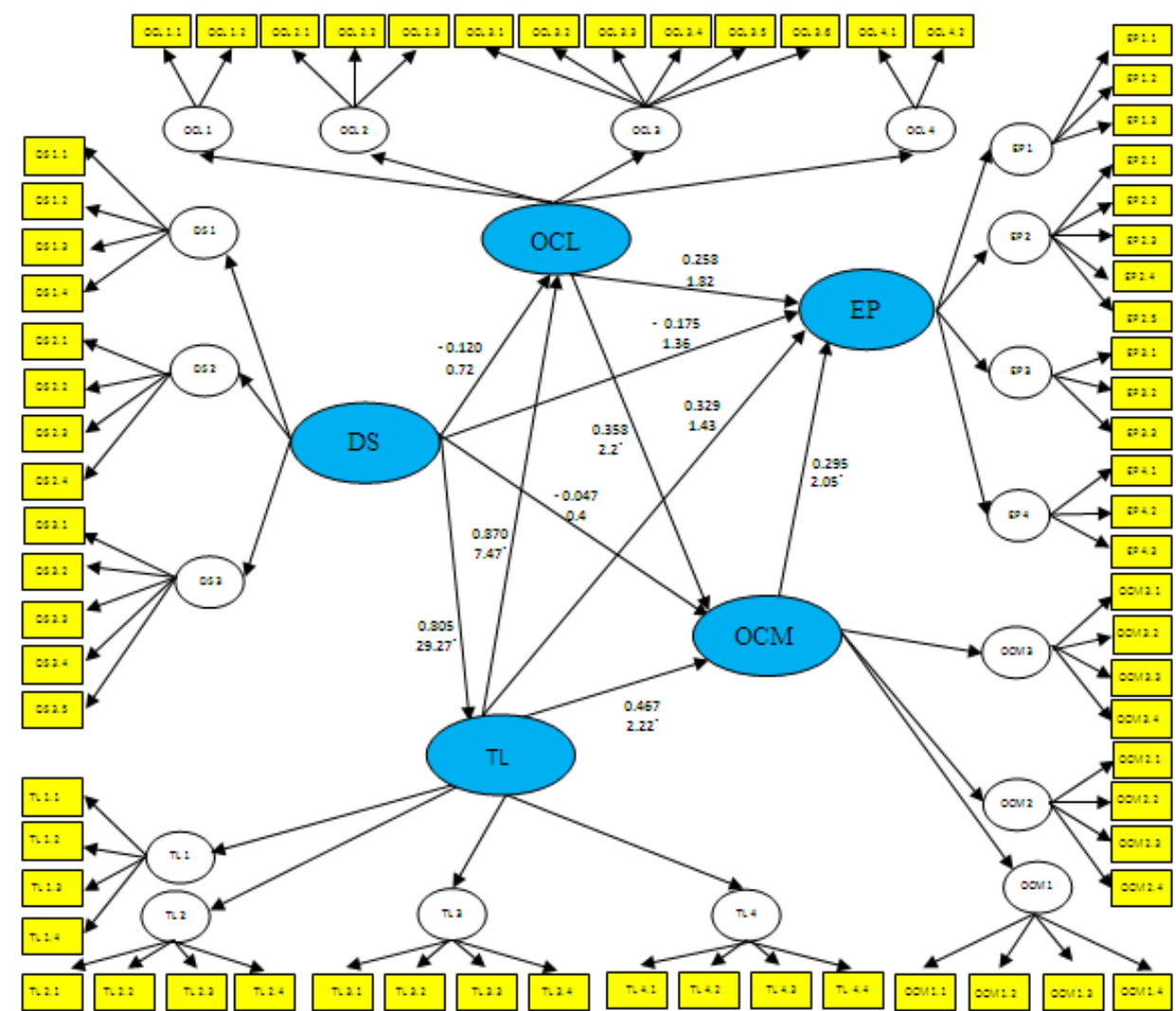

Figure 1. Overal Model

Table 4. Goodness of Fit

\begin{tabular}{|c|c|}
\hline \multicolumn{2}{|c|}{ Model Fit } \\
\hline FIT & 0.529 \\
\hline AFIT & 0.518 \\
\hline GFI & 0.999 \\
\hline SRMR & 0.077 \\
\hline NPAR & 148 \\
\hline
\end{tabular}

Tests showed FIT model fit was 0.529 , so we can conclude that research model is able to explain about $52.9 \%$ variation in the data. Furthermore, both GFI and SRMR values indicate a good level of overall model fit or model fit both the GFI $=0.999$ and $\mathrm{SRMR}=0.077$ (GFI $>0.90$ and $\mathrm{SRMR}$ close to zero)

Hypothesis Testing

Table 5. Path Coefficients

\begin{tabular}{|l|c|c|c|}
\hline \multicolumn{4}{|c|}{ Path Coefficients } \\
\hline DS->TL & Estimate & SE & CR \\
\hline DS->OCL & 0.805 & 0.027 & $29.27^{*}$ \\
\hline DS->OCM & -0.120 & 0.167 & 0.72 \\
\hline DS->EP & -0.047 & 0.118 & 0.4 \\
\hline TL->OCL & -0.175 & 0.129 & 1.36 \\
\hline TL->OCM & 0.870 & 0.116 & $7.47^{*}$ \\
\hline TL->EP & 0.467 & 0.210 & $2.22^{*}$ \\
\hline OCL->OCM & 0.329 & 0.230 & 1.43 \\
\hline OCL->EP & 0.358 & 0.163 & $2.2^{*}$ \\
\hline OCM->EP & 0.258 & 0.141 & 1.82 \\
\hline
\end{tabular}

$\mathrm{CR}^{*}=$ significant at .05 level

Inner estimation results for the model the direct effect of downsizing on transformational leadership is 0.805 and shows the value of CR was $29.27^{*}$, which means it shows that the direct effect of downsizing on transfomasional leadership is positive and significant. 
Inner estimation results for the model the direct effect of downsizing on organizational climate at 0.120 and showed the value of $\mathrm{CR}$ was 0.72 , which showed that the direct effect of downsizing on organizational climate is negative and not significant.

Inner estimation results for the model the direct effect of downsizing on employee performance at 0.175 showed the value of $\mathrm{CR}$ was 1.36 , so it shows that the direct effect of downsizing on employee performance is negative and not significant.

Inner estimation results for the model the direct effect of downsizing on organizational commitment at -0.047 showed CR value was 0.4 , which shows that the direct effect of downsizing on organizational commitment is negative and not significant.

Inner estimation results for the model the direct effect of transformational leadership on organizational climate at 0.870 shows the value of $\mathrm{CR}$ at $7.47^{*}$, which shows that the direct effect of transformational leadership on organizational climate is positive and significant.

Inner estimation results for the model the direct effect of transformational leadership on organizational commitment at 0.467 shows the value of $\mathrm{CR}$ at $2.22^{*}$, which shows that the direct effect of transformational leadership on organizational commitment is positive and significant

Inner estimation results for the model the direct effect of transformational leadership on employee performance at 0.329 showed the value of $\mathrm{CR}$ at 1.43 , so it shows that the direct effect of transformational leadership on employee performance is positive and not significant.

Inner estimation results for the model the direct influence of organizational climate on organizational commitment at 0.358 shows the $\mathrm{CR}$ value at $2.2^{*}$, which shows that the direct effect of organizational climate on organizational commitment is positive and significant.

Inner estimation results for the model the direct influence of organizational climate on employee performance was 0.258 showed $\mathrm{CR}$ value was 1.82 , which shows the direct influence of organizational climate on employee performance is positive and not significant.

Inner estimation results for the model the direct effect of organizational commitment on employee performance was 0.295 showed the value of CR was $2.05^{*}$, which shows that the direct effect of organizational commitment on employee performance is positive and significant.

Hypothesis testing of that indirect effect can use the Sobel formula, as follows:

$\mathrm{Sab}={\sqrt{b^{2} S a^{2}+a^{2} S b^{2}+S a^{2} S b}}^{2}$

$\mathrm{a}=\mathrm{b} 1$ to $\mathrm{b} 2$

$\mathrm{b}=\mathrm{b} 2$ to $\mathrm{b} 3$

$\mathrm{Sa}=$ standard error b1 to $\mathrm{b} 2$

$\mathrm{Sb}=$ standard error $\mathrm{b} 2$ to $\mathrm{b} 3$

Then to test the significance of the indirect effect, it is necessary to calculate the value of $t$ from the $a b$ coefficient as follows:

$t=\frac{a b}{S a b}$

$\mathrm{ab}=(\mathrm{b} 1$ to $\mathrm{b} 2) *(\mathrm{~b} 2$ to $\mathrm{b} 3)$

The results of the calculation for the indirect effect and the value of $t$ are as follows:

Table 6. The results of $t$ value in the indirect effect

\begin{tabular}{|c|l|c|c|c|c|c|c|c|}
\hline No & $\begin{array}{c}\text { The path of indirect } \\
\text { effect }\end{array}$ & $\mathrm{a}$ & $\mathrm{b}$ & $\mathrm{ab}$ & $\mathrm{sa}$ & $\mathrm{sb}$ & $\mathrm{sab}$ & $\mathrm{t}$ \\
\hline 1. & DS-TL-OCL & 0.805 & 0.870 & 0.700 & 0.027 & 0.116 & 0,096 & 7,270 \\
\hline 2. & DS-TL-OCM & 0.805 & 0.467 & 0,376 & 0.027 & 0.210 & 0,170 & 2,216 \\
\hline 3. & DS-TL-EP & 0.805 & 0.329 & 0.265 & 0.027 & 0.230 & 0,185 & 1,428 \\
\hline 4. & DS-OCL-OCM & -0.120 & 0.358 & $-0,043$ & 0.167 & 0.163 & 0,069 & $-0,627$ \\
\hline 5. & DS-OCL-EP & -0.120 & 0.258 & -0.031 & 0.167 & 0.141 & 0,052 & $-0,596$ \\
\hline 6. & DS-OCM-EP & -0.047 & 0.295 & -0.014 & 0.118 & 0.144 & 0,039 & $-0,353$ \\
\hline 7. & TL-OCL-OCM & 0.870 & 0.358 & 0.311 & 0.116 & 0.163 & 0,149 & 2,091 \\
\hline 8. & TL-OCL-EP & 0.870 & 0.258 & 0.224 & 0.116 & 0.141 & 0,127 & 1,763 \\
\hline 9. & TL-OCM-EP & 0.467 & 0.295 & 0.138 & 0.210 & 0.144 & 0,096 & 1,431 \\
\hline 10. & OCL-OCL-KK & 0.358 & 0.295 & 0.106 & 0.163 & 0.144 & 0,074 & 1,421 \\
\hline
\end{tabular}

Indirect effect coefficient between downsizing on the climate of the organization through leadership transfomasional was 0.700 , then it can be seen the value of t-statistics was 7.270 , where the value is greater than t-table $1.985(\mathrm{n}=96, \alpha=5 \%)$, suggesting an indirect effect downsizing of organizational climate through transformational leadership is significant.

Indirect effect coefficient between downsizing on organizational commitment through leadership transfomasional was 0.376 , then it can be seen the value of t-statistics was 2.216 , where the value is greater than 
t-table 1.985 ( $\mathrm{n}=96, \alpha=5 \%$ ), suggesting an indirect effect downsizing on organizational commitment through transformational leadership is significant.

Indirect effect coefficient between downsizing on employee performance through leadership transfomasional was 0.265 , then it can be seen the value of t-statistics was 1.428 , where the value is smaller than t-table $1.985(\mathrm{n}=96, \alpha=5 \%)$, suggesting an indirect effect downsizing on employee performance through transformational leadership is not significant.

Indirect effect coefficient between downsizing on employee performance through organizational climate at -0.031 , then it can be seen the value of t-statistics at -0.596 , where the value is smaller than t-table $1.985(\mathrm{n}=96, \alpha=5 \%)$, indicating the indirect influence downsizing on employee performance through organizational climate is not significant.

Indirect effect coefficient between downsizing on employee performance through organizational climate at -0.043 , then it can be seen the value of t-statistics at -0.627 , where the value is smaller than $t$-table $1.985(\mathrm{n}=96, \alpha=5 \%)$, indicating the indirect influence downsizing on organizational commitment through organizational climate is not significant.

Indirect effect coefficient between downsizing on employee performance through organizational commitment at -0.014 , then it can be seen the value of t-statistics at -0.353 , where the value is smaller than $\mathrm{t}$ table $1.985(\mathrm{n}=96, \alpha=5 \%)$, indicating that indirect effect of downsizing on employee performance through organizational commitment is not significant.

Indirect effect coefficient between transformational leadership on organizational commitment through organizational climate was 0.311 , then it can be seen the value of t-statistics at 2.091 , where the value is greater than t-table $1.985(\mathrm{n}=96, \alpha=5 \%)$, indicating that indirect effect of transformational leadership to organizational commitment through organizational climate is significant

Indirect effect coefficient between transformational leadership on employee performance through organizational climate was 0.224 , then it can be seen the value of t-statistics was 1.763 , where the value is smaller than t-table $1.985(\mathrm{n}=96, \alpha=5 \%)$, indicating that indirect effect transformational leadership on employee performance through organizational climate is not significant.

Indirect effect coefficient between transformational leadership on employee performance through organizational commitment at 0.138 , then it can be seen the value of t-statistics at 1.431 , where the value is smaller than t-table $1.985(\mathrm{n}=96, \alpha=5 \%)$, indicating that indirect effect transformational leadership on employee performance through organizational commitment was not significant

Indirect effect coefficient between organizational climate to employee performance through organizational commitment was 0.106 , then it can be seen the value of t-statistics was 0.690 , where the value is smaller than t-table $1.985(\mathrm{n}=96, \alpha=5 \%)$, indicating that indirect effect organizational climate to employee performance through organizational commitment is not significant.

\section{Conclusions and Discussion}

The result showed the fact that downsizing had a negative impact on organizational climate, organizational commitment and employee performance, eventhough unsignificant. The negative impact of downsizing can be minimized through transformational leadership role.

Transformational leadership has an important and decisive role in mediating the effects of downsizing on organizational climate, organizational commitment and employee performance. Thus, in managing downsizing need to use the important role of transformational leadership to optimize the achievement of organizational goals. In addition, transformational leadership in this study is a new thing that has not been previously studied mainly associated with downsizing.

Organizational climate is a variable that is susceptible to both positive and negative influences. When downsizing occurs organizational climate variables have the greatest negative effect as well as to the transformational leadership also has the greatest influence, be a positive influence. Thus, when there is downsizing, leaders need to pay attention to this variable. Because it can become opportunities and threats in achieving the objectives for the implementation of downsizing.

\section{Implication for management}

Application of downsizing will be more effective if it is supported by practices of transformational leadership that is able to build a conducive organizational climate and be able to improve organizational commitment. Prominent indicators of transformational leadership is effective communication between employees and supervisors.

\section{Reference}

[1]. Appelbaum, S.H., Simpson, R. and Shapiro, B.T. (1987), Downsizing: the ultimate human resource strategy, Business Quarterly, Vol. 52 No. 2, pp.52-60. 
[2]. Appelbaum, Steven H., Everard, Andrea, \& Hung, Loretta T.S., (1999) Strategic downsizing: critical success factors, Management Decision, Vol. 37 No. 7, pp. 535-552

[3]. Bass, B.M. (1985) Leadership and performance beyond expectations, Free Press, New York

[4]. Cascio, Wayne F., (1993) Downsizing: What Do We Know ? What We Have Learned?, JSTOR: The Executive, Vol.7 no 1 (Feb 1993) pp. 95-104

[5]. Cascio, W.F. and Wynn, P. (2004) Managing a downsizing process, Human Resource Management, Vol. 43 No. 4 , pp. $425-436$.

[6]. De Clercq, Dirk \& Rius, Imanol Belausteguigoitia (2007) Organizational Commitment in Mexican Small and Medium-Sized Firms: The Role of Work Status, Organizational Climate and Entrepreneurial Orientation, Journal of Small Business Management Vol. 45 (4), pp. 467-490

[7]. Erickson, Robin Adair \& Michael E. Roloff (2007) Reducing Attrition After Downsizing, Analyzing The Effect of Organizational Support, Supervisor Support, and Gender on Organizational Commitment, International Journal of Organizational Analysis Vol.15 No. 1, 2007 pp.35-55.

[8]. Guthrie, James P. \& Deepak K. Datta (2008), Dumb And Dumber: The Impact of Downsizing on Firm Performance as Moderated by Industry Conditions, Organization Science Vol 19, No 1, Januari - February 2008, pp 108 -123

[9]. Hitt, M. A., Hoskisson, R. E.,Harrison J. S., and Summers, T. P. (1994) Human capital and strategic competitiveness in the 1990s, Journal of Management, Vol. 13 No. 1, pp. 35-64

[10]. Kangis, P. \& Williams, D.G.S. (2000) Organisational climate and corporate performance an empirical investigation, Management Decision 38/8, pp. 531-540.

[11]. Lâmsâ, Anna Maija \& Taina Savolainen (2000) The Nature of Managerial Commitment to Strategic Change, Leadership \& Organization Development Journal, Vol. 21 No. 6, 2000 pp. 297-306.

[12]. Lee, Jaewon \& Corbet, J. Martin (2006) The Impact of downsizing on employees' affective commitment, Journal of Management Psychology, Vol. 21 No. 3, 2006 pp. 176-199

[13]. McKinley, W., Zhao, J. and Rust, K.G. (2000) A Socio-cognitive interpretation of organizational downsizing, Academy of Management Review, Vol. 25 No. 1, pp. 227-243.

[14]. McMurray, A.J., Pirola-Merlo, A., Sarros, J.C.; Islam, M.M. (2010) Leadership, Climate, Psychological Capital, Commitment, and Wellbeing in a non-profit Organization, Leadership \& Organization Development Journal Vol. 31 No.5, 2010 pp. $436-457$

[15]. Meyer, J.P. \& Allen, N.J. (1991) A three-component conceptualization of organizational commitment: Some methodological considerations, Human Resource Management Review, 1, pp. 61-98.

[16]. , (1997) Commitment in the workplace: Theory, research, and application. Thousand Oaks, CA: Sage

[17]. Ramachandran, S. \& Krishnan, V.R. (2009) Effect of transformational leadership on followers' affective and normative commitment: culture as moderator, Great Lakes Herald, Vol. 3 No. 1, pp. 23-38

[18]. Robbins, S.P. (1994) Teori Organisasi, Struktur, Desain \& Aplikasi, edisi 3, alih bahasa Jusuf Udaya, Arcan, Jakarta.

[19]. Sandbakken, Dag A. (2006) Leadership Practices and Organizational Performance- a Norwegian Study, EDAMBA Journal.

[20]. Sheaffer, Z; Carmeli, A; Steiner-Revivo, M.; Zionit, S (2009) Downsizing Strategies and Organizational Performance: a Longitudinal Study, Management Decision Vol.47 No. 6, 2009 pp. 950-974.

[21]. Sitlington, H. \& Marshall, V. (2011) Do Downsizing Decisions Affect Organisational Knowledge and Performance ?, Management Decisions Vol.49 No.1, pp.116-129.

[22]. Theissen, Christine (2004) The impact of organisasional restructuring on employee commitment at the otago polytechnic, MBUS project

[23]. Tsai, Cheng-Fei \& Yen, Yu-Fang (2008) A Model to Explore The Mystery Between Organizations' Downsizing Strategis and Firm Performance, Journal of Organizational Change Management, Vol. 21 No. 3, 2008 pp. 367-384

[24]. Turknett, Carolyn (2009) Revitalization after Downsizing: A Briefing for Leaders, www.Turknett.com downloaded at Juni, 13, 2013

[25]. Tzafrir, Shay S.; Mano-Negrin, R; Harel G. H.; Rom-Nagy, D (2006) Downsizing and The Impact of Job Counseling and Retraining on Effective Employee Responses, Career Development International Vol. 11 No. 2, 2006 pp. $125-144$. 